\title{
Study on the Construction of E-Commerce Brand Integration of Agricultural Products under the Environment of "Internet ${ }^{+}$"
}

\author{
Xuewei Li \\ Dept. economic and management \\ Wenhua College \\ Wuhan, China
}

\author{
Chunying Cui \\ Dept. economic and management \\ Wenhua College \\ Wuhan, China
}

\begin{abstract}
Agricultural e-commerce has been a short board of the Internet applications, consumers for agricultural products low brand awareness directly affect the brand could bring premium and value, how to scientifically and reasonably upgrade, will be agricultural industry chain each link of enterprise need deep thinking and problems. Through the study of "Internet+ agriculture" the difficulties and challenges, and analyzes the operation difficulties in the actual construction of the ecommerce of agricultural products brand, summed up the countermeasures and suggestions of construction of electronic commerce brand integration of agricultural products, expect to have a positive impact on the development of e-commerce of agricultural products.
\end{abstract}

Keywords-Internet+; E-Commerce of agricultural products; brand of agricultural products; Agricultural modernization

\section{INTRODUCTION}

Faced with a strong invasion of foreign agricultural products, the competitiveness of domestic agricultural products is declining, overcapacity and homogenization of competition has led to the gradual loss of the market. At the same time, but also enjoy high quality agricultural products for city residents, consumers for agricultural products low brand awareness directly affect the brand could bring premium and value-added upgrade imminent transformation of traditional agricultural enterprises. Whether it is the retail terminal, terminal, terminal channel brand, production, circulation or end, even the regional market, the local life services market are facing great challenges and opportunities for the redistribution of resources, how to scientifically and reasonably upgrade, will be the agricultural product industry chain each link of enterprise need deep thinking and face the problem.

\section{BRAND CONSTRUCTION OF AGRICULTURAL PRODUCTS IS THE INEVITABLE REQUIREMENT OF THE DEVELOPMENT OF MODERN AGRICULTURE}

As a major agricultural country with a major impact on the world, China still lacks a regional brand with international competitiveness. Many agricultural products still belongs to labor and resource intensive, quality level compared with the international advanced level there is still a wide gap, agricultural products are still not able to stabilize the market,

The study was supported by Humanities and social sciences research project of Hubei(china) Provincial Department of Education (No. 2016GB176) agricultural enterprises in a passive position in the international competition in the domestic market. Facing the new situation of the domestic and international market competition and resource environment intensified, China's traditional competitive advantage is gradually weakening, foster new competitive advantage of agricultural products is imminent, to nurture and enhance the ability of independent innovation is an important way to Chinese regional brand new competitive advantage of size.

"Internet + agriculture" is to make full use of the mobile Internet, big data, cloud computing, cross-border networking and other new generation of information technology and the integration of agriculture, modern agriculture innovation Internet platform of new products, new models and new formats based on. "Internet + agriculture" drive to create "information support, management synergy, production efficiency, product safety, resource saving and environment friendly" upgrade version of the development of modern agriculture in china. "Internet + agriculture" must strengthen brand building, and effectively improve the quality of the overall level of China's agricultural products, accelerate the development of a number of independent intellectual property rights and quality of national brand competitiveness and regional brand of agricultural products, to further increase the international competitiveness of China's agricultural industry, and strive to achieve the increase of farmers' income, agricultural efficiency and promote the implementation of the situation. The strategy of China's expanding domestic demand.

\section{THE CHALLENGE OF THE CONSTRUCTION OF AGRICULTURAL PRODUCTS E-COMMERCE BRAND}

Compared with other industries, agricultural products as the brand development of virgin land, has been in the commercial brand edge. The lack of large brands, the brand of agricultural products is still long and arduous road. In a fully competitive era, the market is not lack of products, lack of brand creativity and marketing can move consumers. To strengthen the brand marketing of agricultural industrialization, to create a famous brand of agricultural industrialization, and to drive the sustainable development of the agricultural industry is particularly important. The development speed of the electricity supplier of agricultural products quickly, from 
agricultural brand marketing agencies have recently coming to the fore can see that demand continues to increase. However, there are many problems in the brand building of agricultural products, which makes it difficult to set up the brand.

\section{A. Many electronic business platforms are the same}

At present, the electricity supplier of agricultural products has more than 4000, and the number of the electricity supplier of agricultural products is increasing, but only $1 \%$ in earnings, $4 \%$ flat, $95 \%$ in losses, which is a huge loss of $7 \%$. These agricultural electricity suppliers of the site is generally prominent problem is: convergence investment, duplication of construction is very common; homogenization serious, leading to disorderly competition, loss of business; lack of market analysis, service quality is worrying. In recent years, there have been many cases of failure of fresh agricultural electricity suppliers, are the consequences of these reasons.

\section{B. The degree of standardization of agricultural products is low}

The competition of agricultural product market can be said to be the competition of agricultural product brand, which is not only related to the agricultural industrialization, but also closely related to the standardization of agricultural products. The level of the electricity supplier industry standards of agricultural products is relatively low performance in two aspects: one is the lack of quality standards of agricultural products, agricultural products in the production process there is no standard to follow or not the standard, resulting in a lack of credibility of the quality of agricultural products; the two is the lack of circulation of the standard, such as lack of sorting standard, packaging standard distribution, standards, management standards and acceptance criteria.

\section{Agricultural electricity suppliers talent gap}

With the Internet, the agricultural modernization process, the emergence of a group of domestic culture, innovation, organization, the Internet thinking of agricultural producers and guide, namely the new farmers. The new farmer has four genes, respectively, is the Internet thinking, innovation consciousness, self-organization and culture, but also has ecological concept, they are the mainstream force to promote the development of the rural modernization. Talent is the most crucial problem, the emergence of new farmers to a certain extent will alleviate this dilemma, but we also see that compared with the huge agricultural business market, talent gap is still very large, the maximum threshold market is far from top left, agricultural electricity supplier in the field of the new entrant into the time and there is much room.

\section{Agricultural industry chain link information asymmetry}

The modern agricultural industrial chain is a new industrial organization, it is a huge scale and complex structure of mesh elements of the system, through the agriculture antenatal, intrapartum and postpartum in 3 major areas, including links to antenatal, production processing circulation and consumption 5 links. At the same time, each part of the chain corresponds to the field of agricultural production of different functions, the main implementation of these functions include the social service institutions, enterprises or cooperatives, professional farmers and agricultural cooperatives. At present, the 5 links of domestic agricultural industry chain are scattered, lack of convergence and constraints, the overall degree of disorder in the industry is higher, from production to consumption of the whole process of information and price transmission mechanism is not smooth. On the one hand to control the quality of agricultural products, an industrial chain of any part, are likely to cause food safety accidents. On the other hand, the individual farmers can not grasp and determine the market demand accurately, in the entry and exit barriers are low, the whole agricultural production fluctuation, individual farmers or small agricultural enterprises bear a higher risk, income is not stable.

\section{E. Cold chain logistics with speed difficult to meet}

The electricity supplier of agricultural products, cold chain is always unavoidable problem, not only to build your warehouse, mixed delivery vehicles also must be refrigerated + frozen and refrigerated containers, and the thermostatic device, otherwise the goods sent to the customer, there will be a problem of goods. Cold chain investment is not a general agricultural products business enterprise can do well, continuous asset investment, long payback period, is allocated to each piece of agricultural product cost greatly, this is the problems faced by the electricity supplier of agricultural products. Even if there is capital investment, but the order of the seasonal and unstable, it will make the electricity suppliers operating costs greatly wasted. Therefore, the socialization of the cold chain logistics team, intensive, specialized management has become an urgent need of resources for the entire agricultural electricity suppliers.

\section{AGRICULTURAL PRODUCTS E-COMMERCE BRAND INTEGRATION STRATEGY}

Construction of electronic business integration of agricultural products need to involve multiple subjects, including agricultural products brand enterprises, circulation enterprises, wholesale markets, agricultural enterprises, agricultural products business platform, agricultural tourism enterprises, etc..

\section{A. Establish the quality standards of agricultural products and agricultural products traceability system}

Traceability system of quality safety management of agricultural products and comprehensive use of a variety of network technology, barcode recognition technology, the realization of agricultural production and circulation process of the information management and the quality of agricultural products traceability management, agricultural production records (the production environment, production process, quality inspection) management, barcode label design and printing, based on quality and safety traceability and other web sites and mobile phone SMS platform function. To formulate the quality standard of agricultural products from the production environment (soil, water, air, etc.) the production process (fertilizers, pesticides, growth regulators, such as fertilizer application methods, application time, and application of the number of technical regulations) to product quality 
(appearance, nutrition, health, quality etc.) (Preservation, storage, processing and packaging grading and packing etc.) a series of standards and other aspects, so that every link in the production of agricultural products are included in the standard management of the track, the formation of the whole standard index system of a set of perfect, to the quality of agricultural products from the soil to the whole process control table. The agricultural products traceability system to allow consumers to directly back to each product origin, producer, production process and other information, as well as its quality standards, and further enhance the production and marketing of both ends of the trust, enhance the cohesive relations between production and marketing.

\section{B. Construction of the value of the regional agricultural industry chain}

To build a perfect and efficient agricultural industry chain, need a point to a line, from line to surface, the need to proceed from the refinement chain, time integration backbone, two run parallel. First of all, to fully develop the weak sub chain. In a single link, to break the small-scale production mode, the secondary chain such as agricultural procurement, production of planting and sowing irrigation, fertilizer harvest each link and specialization will be fully refined, farmers are not good, not economic function is separated, by the special procurement, irrigation, harvesting and other agencies to undertake, improve efficiency; secondly, to achieve the main chain order. Each link in the basis of specialization, to the organization of farmers industry leading enterprises or the strength of the main business integration, open up the industry chain of 5 links, combine marketing, production and marketing, dredge the information and price transmission mechanism, change the industry chain of scattered and disorderly situation; in addition, to the organization of farmers dispersed and embedded industrial chain, to participate in market competition in the form of agricultural cooperatives or cooperatives, which is the core of development of modern agricultural industrial chain organization system. On the one hand, can effectively change the individual farmers in a disadvantaged position during the competition, reduce risk and improve profit; on the other hand, can effectively concentrate the needs of farmers, promote professional services and growth, improve efficiency of integration of industry chain. The future of agriculture industry chain management, is to fully function in various professional segments on the chain link at all levels into an organic whole, and the elements of the human, financial and material resources, information and technology flow organization, coordination and control, to enhance the value of the whole industry chain and get the terminal agricultural product brand premium.

\section{Do a good job in the construction and operation of agricultural products platform}

Agricultural business platform should be based on a sense of service to build brand, its design will need to serve as a guide to mobilize them to participate in the interaction, but also allow customers to have a sense of identity, sense of belonging and sense of self realization of the website, can open on the site to open field evaluation of customer service, customer success stories, the story bar bar the emotional service program. Emotional services can melt the social value, cultural value, enterprise value in one, can be a part of the potential customers into direct customers, the formation of brand loyalty. In addition, advertising communication, news communication and public relations are essential.

Agricultural products business platform only through innovation to meet the growing needs of customers, in order to maintain the vitality of the brand. Electronic business innovation requires service and business philosophy of innovation at the same time, service innovation is the basis of maintaining the brand vitality, and business philosophy is the source of sustainable development of the brand.

\section{Do a good job in the whole network operation and promotion of agricultural products brand}

The operation and promotion of agricultural product brand can be carried out from the aspects of product packaging, mass communication, public praise communication and public relations.

Packaging is an important part of the brand image. It is not only a direct reflection of the brand image, but also the main carrier of the brand continued to spread. Exquisite, flexible, practical, distinctive characteristics of the packaging and product characteristics, it will quickly and directly stimulate the consumer's desire to buy, they will play a more lasting promotional role.

Mass media is the main tool of agricultural product brand promotion. According to the market positioning of agricultural products to determine the advantages of products, accurate grasp of the real needs of consumers, selling point to clear, to guide and affect their awareness of agricultural products, preferences and final choice. Generally speaking, in advertising, the advertising appeal should be consistent with the product of the target customers, advertising promotion should be consistent with the propagation characteristics of products, advertising promotion should be consistent with the target market, advertising should be synchronized with the life cycle of the product, and choose the best time to receive the target customer.

Consumption of agricultural products is a focus on the quality of consumption, and the quality of the experience can only be perceived. Word of mouth has become one of the most effective means of agricultural product brand promotion. Word of mouth is to let the people satisfied with the relatives and told him, when talking between relatives and friends, people are not defensive, information can directly reach the audience's heart, the persuasive than advertising, public relations and any other ways to promote persuasion are stronger. The essentials of word-of-mouth is the quality of the product is really good, to summarize the characteristics of the product are consciously, better generalization or easy to understand and easy to remember, Lang Lang is humorous language communication effect.

Public relations are mainly through shaping the corporate image, improve enterprise or product visibility and reputation, for the public to leave good impression, indirectly promote the sales of the product brand promotion. The public relations strategy for the brand promotion of agricultural products are: 1 . 
In the event, sports event or anniversary ceremonies, competitions, exhibitions, lectures and other special activities, strengthen communication with the public, transfer to the public enterprise dynamic, expand the brand influence of agricultural products; the public welfare activities. Can be supported or to education, environmental protection, charitable giving way to win public praise, establish a good brand image; media reports. News, special reports, field interviews and other media reports have a high authority, authenticity and knowledge. Although the promotion of public relations slow, but the image of the brand is very effective in shaping and dissemination, the use of clever words, often have a multiplier effect.

\section{E. Strengthen the deep processing of agricultural products, mining products of high value}

The operation and promotion of agricultural product brand can be carried out from the aspects of product packaging, mass communication, public praise communication and public relations.

Agricultural market is a natural high homogeneity of the market, the common product of its product value and added value is low, the more fresh food, and the more serious homogenization. Such products can only be put into the market, only the price of the price, and the results, who can not sell a good price. Only the deep processing of products, in cooperation with relevant research institutions, the depth of mining product value, or change the original form of products, greatly enhance the added value of products, the same product becomes completely out of the ordinary. For example, pumpkin, a crop is very unusual, through cooperation with research institutions, the pumpkin is divided into four categories: skin, flesh, flesh, and many fields of products related to food, cosmetic and medical treatment, can also export, calculation of value added to 100 times. Agricultural products to do the difficulty of the brand and the depth of processing is inversely proportional, that is, with the degree of processing more and more deep, the difficulty of making the brand gradually reduced, and vice versa. Cold meat brand is very difficult, but the meat processing made of ham sausage, the brand is relatively easy; similarly, fresh fruits and vegetables. The brand is very difficult, after processing, canned vegetables, fruits and vegetables do brand is relatively easy. Deep processing is the product differentiation, the value of the magic of the magic. Deep processing can greatly increase the convenience and hygiene of agricultural products, easy storage and transportation, these value-added in the needs of consumers to find the end result. Many research institutions have the results, but not the transformation vector, sometimes a lot of people in the capital, financing, and the use of resources, cooperation or leveraging is a good way.

\section{F. Promote the combination of agriculture and Tourism}

Leisure agriculture is the use of agricultural landscape resources and agricultural production conditions, a new type of agricultural industry development of sightseeing, leisure and vacation tourism; deep development of agricultural resources, the adjustment of agricultural structure, improve agricultural environment, and increase farmer income. Rural tourism is far away from the urban area to the countryside as the destination, taking the rural unique natural and cultural landscape as attraction, taking urban residents as the main target market, through to meet tourists for leisure, a travel demand and return to nature and get economic and social benefit. In the leisure agriculture area, visitors can not only sightseeing, harvesting, harvest of agricultural products, experience farming, farmers understand the life, enjoy the local taste, and lodging, vacation, recreation, and even part of the labor process can make tourists personal participation and experience. Leisure agriculture can also through the form of entertaining, let participants cherish the nature of rural cultural resources, arouse people love of work, love life, love nature, interest, and further enhance the people to protect the natural and cultural heritage protection, protect the environment consciousness. Development of tourism projects, enhance tourism experience. The ultimate goal of tourists is to pursue a happy experience; in the development of rural tourism should be designed rich, vivid experience of the project, to meet the experience of tourists and their personalized travel needs. In addition, the development of traditional arts and crafts and agricultural products should be increased to provide rich tourist souvenirs, increase the consumption expenditure of tourists, and promote the development of rural economy.

In summary, the future development of agricultural products business, the brand is an important basis for the electricity business era, the opportunities and challenges of agricultural brand. At present, our country is in great changes in consumption structure, consumer demand for green health food, strengthen the agricultural product promotion and brand marketing to get through two pronged approach, the era of electricity supplier of agricultural products. As the marketing of agricultural products, from the source to the choice of varieties, strengthen quality management, and the formation of standard, dug up the story, good product phase in the product form and packaging, to a solid foundation for the agricultural product brand, variety, quality and quality of interaction of the three China Unicom promotion, brand to be broke may.

\section{REFERENCES}

[1] Banker R D, Mitra S. Procurement models in the agricultural supply chain:A case study of online coffee auctions in India[J]. Electronic Commerce Research and Applications,2007,6:309 - 321.

[2] Norbert N, Thomas Q, Sibylle K. Information and its management for differentiation of agricultural products: The example of specialty coffee[J].Computers and Electronics in Agriculture,2008,61:24-253.

[3] Ruiz Garcial, STEINBERGER G, ROTHMUND M. A model and prototype implementation for tracking and tracing agricultural batch products along the food chain[J].Food Control,2010,21:112-121.

[4] Jiang Qian. American agricultural products e-commerce model to China inspiration [J]. world agriculture, 2015 (10)

[5] Li Jingjing, Kang Xingyu, Yang Shuo. The selection of the development mode of fresh agricultural products in China $[\mathrm{J}]$. business economic research, 2015 (13)

[6] Turban E.et al. Electronic Commerce:A Managerial Perspective.5th ed[M].New Jersey:Prentice Hall Press.2008 